\title{
"KRIZA IMA VEČ PODOB, REŠITEV JE ENA: DAJTE LJUDI NA PRVO MESTO«
}

(Sporočilo VI. CONFITEA, svetovne konference Unesca o izobraževanju odraslih, Belem, 2009, Brazilija)

Na 6. CONFITEA, svetovni Unescovi konferenci o izobraževanju odraslih 2009, so ugotavljali, da je sedanja ekonomska kriza drugačna od nekdanjih, ker zahteva prevrednotenje vrednot. Kapital in družbeno moč naj bi nadomestil človek kot glavna vrednota: »Izhod iz krize: postavite ljudi na prvo mesto «. Moč kapitala in tržno gospodarstvo sta povzročila »turbokapitalizem«: koncentracijo 90 odstotkov kapitala v rokah peščice ljudi na eni strani, revščino množic in s tem slabe možnosti za izobraževanje in zdravstvo na drugi. Vlade se obotavljajo pri uvedbi novega sistema obdavčenja kapitala, ker jih je kapital spravil v podrejen položaj. Socialne države izginjajo, vlade se s socialnimi problemi ne ukvarjajo več, kvečjemu z zakoni porajajo nove. Podjetja so podvržena ekonomski logiki. Socialne funkcije vedno bolj opravljajo neprofitne organizacije, razna društva, združenja, mednarodna in nacionalna (Adult Education and Development, 2010).

Govorimo o funkcionalni nepismenosti brezposelnih industrijskih delavcev. Na nove delovne razmere $v$ informacijski družbi niso pripravljeni in se ne morejo več ustrezno odzivati na spremembe v okolju. Kdo jih bo preživljal? Zdaj tudi pri nas na zavodu za zaposlovanje odprto govorijo o največji kategoriji brezposelnih: trajno brezposelnih. To so ljudje, ki so zaostali za razvojem. Trg dela $v$ informacijski družbi zahteva vsaj višjo ali visoko izobrazbo, računalniško pismenost in poznavanje tujih jezikov, ker je nacionalni trg zamenjal svetovni.

Za razvoj človeških virov si v Sloveniji prizadevamo na več načinov. Ministrstvo za javno
UVODNIK

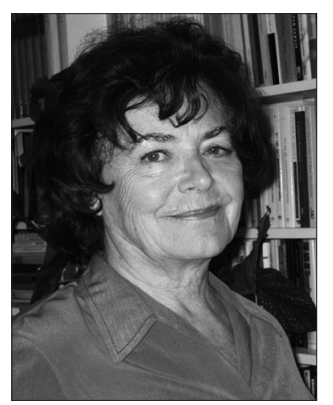

upravo v okviru evropskih sredstev že nekaj let z večjimi projekti načrtno podpira razvoj društev in povezovanje mrež društev (Zvezo tabornikov Slovenije, mrežo Slovenska univerza za tretje življenjsko obdobje, mrežo društev za ohranjanje kulturne dediščine, izobraževalna in kulturna društva, društva upokojencev). S tem se ustvarja socialni kapital za premagovanje funkcionalne nepismenosti po poteh neformalnega izobraževanja.

\section{DRUŽBA ZNANJA, STROKOVNJAKI ALI DELAVCI ZNANJA}

Sodobna organizacija je »organizacija znanja« in zaposleni so delavci znanja. Posodobljena tehnologija (brez nje delodajalec na svetovnem trgu ni konkurenčen, nacionalni trgi pa so v glavnem izginili) je obrnila odnos med delavcem in strojem. Zdaj delavec določa, kaj bo stroj delal. Brez človeka z znanjem je stroj neproduktiven in zmožnosti nove tehnologije ostanejo neizkoriščene.

Letos so pri IBM izdelali zelo pameten računalnik, imenovan Watson. Na kvizu je premagal vse doslej najuspešnejše tekmece, čeprav na nekatera vprašanja ni znal odgovoriti (npr. ali je Slovenija v EU). Deloval je hitreje od človeških možganov. Toda to je samo reprodukcija milijonov naloženih informacij in hitrejša izbira, kar omogoča računalniška tehnologija. Ne more proizvesti inovacij, ustvarjati nove razsežnosti, nove kakovosti, ne more se zanesti na motivacijo, čustva in osebno presojo pri odločanju. 
Zato danes zavračamo šole, ki zahtevajo, da se učenci na pamet učijo raznih informacij, jih za natančno reprodukcijo nagrajujejo $z$ visokimi ocenami, ne naučijo pa jih misliti in čustvovati, da bi delovali kot samostojna bitja.

Ob novi tehnologiji so pri delu za ljudi ostale le najvišje človeške funkcije. Strokovnjak, specialist ima priložnost, da izrazi svoje bistvo. $S$ tem se $v$ novi dobi delo bolj humanizira $v$ primerjavi z industrijsko dobo.

Znanje je postalo glavna proizvodna sila. Strokovnjaki se tega zavedajo. Če odidejo, gre znanje z njimi. Počutijo se svobodne in mobilne. Kapital, oprema, fizično delo in zemljišče so postali drugotnega pomena, ker jih je laže dobiti in sami po sebi, brez strokovnjakov (delavcev znanja), niso produktivni (Drucker, 1995: 75-79).

Reorganizacije podjetij in uvajanje novih tehnologij izločijo prejšnje delavce in pustijo za seboj množico brezposelnih. Januarja letos je bilo v Sloveniji 115 tisoč brezposelnih. V kratkem pričakujemo še nadaljnjih 40 tisoč v glavnem funkcionalno nepismenih ljudi z zelo nizko izobrazbo. »Tehnološki viški«. V organizacijo s sodobno tehnologijo sprejemajo samo visoko izobražene specialiste, strokovnjake ali »delavce znanja«. Za zdaj brezposelne ni bilo strahu, da bi odšli drugam. Bili so odvisni od nekega podjetja in opreme. In nefleksibilni.

Delavci znanja so zelo mobilni. Najpomembnejše proizvodno sredstvo, znanje, imajo $v$ svojih glavah. In z njim odidejo drugam. Tega se delodajalci zelo bojijo. Organizacija zato vloži veliko truda v to, da zadrži delavce znanja, da ne odidejo drugam, preden se projekt zaključi. Omogoči jim delo na domu, pritegne tudi njihove družine na sprostitvene prireditve, jim ponudi izredne finančne nagrade in druge privilegije. Obstajajo posebne službe, »lovci na glave« (head hunters) za novačenje stro- kovnjakov (delavcev znanja). Organizacije si med seboj pulijo kompetentne ljudi.

Najbolj znani strokovnjaki postanejo »nomadni eksperti«. Stalno so po svetu in le za krajši čas delajo za enega delodajalca. Nekateri univerzitetni profesorji, znanstveniki na nekem novem področju, delajo na več univerzah hkrati v Evropi, Ameriki in še na kaki v Aziji. Ta pojav profesorjev nomadov je prerasel prejšnjo obliko gostujočih profesorjev. A tako ni samo $v$ znanosti. Pogodbeno delajo na raznih koncih sveta tudi strokovnjaki za statiko, hidroelektrarne, sončno energijo, avtomobilizem, gozdarstvo, računalništvo itd.

Prejšnji delavci so bili vezani na stroj in podjetje. Priučeni za delo niso imeli veliko izbire, ker je njihovo ozko poklicno znanje imelo omejeno veljavo, samo pri določenem stroju za določen izdelek.

\section{ORGANIZACIJA ZNANJA}

Sedanja ekonomska kriza je kriza vrednot. Podjetja in organizacije nasploh, ki so že prej na prvo mesto med proizvodnimi sredstvi postavili znanje in strokovnjake (delavce znanja), ne čutijo nobene krize. Dela imajo vedno več in na svetovnem trgu odlično uspevajo. Take organizacije so tudi $v$ praksi uresničile trditev, da je znanje edina njihova vrednost in prednost pred drugimi. Tudi v Sloveniji imamo več takih primerov: računalniška podjetja za računalniške programe in aplikacije, podjetje bratov Jakopin za proizvodnjo jadrnic, podjetje Pipistrel za proizvodnjo lahkih letal, turistično podjetje Ars Longa, tovarna zdravil Krka, podjetje Bia Separations z visoko tehnologijo za izdelavo bioloških filtrov za farmacevtsko industrijo, podjetje Ultra za aplikacijo digitalnih informacijskih sistemov itd. Podjetja z zastarelo tehnologijo so s pojavom krize propadala drugo za drugim. $Z$ državnimi sredstvi davkoplačevalcev so jim podaljševali 
agonijo, da bi prestavili socialno krizo na poznejši čas, in sredstva so odtekala po neproduktivni poti, ker je bilo navidezno bolj varno ohranjati staro in preživelo. Novega nas je bilo strah. Soočenje z realnostjo, stanjem človeškega kapitala v Sloveniji, je bilo neizogibno. Danes to neizprosno doživljamo.

Se vprašamo, kdo je odgovoren za človeške stiske in revščino? Kakšno šolsko politiko imamo že 30 let? Zakaj ljudem nismo omogočili, da se razvijejo, ko je bil za to še čas? Napačna izobraževalna politika ni nič drugega kot oblika genocida. Kdo bo sodil politikom, ki še danes, ko znanje pomeni preživetje, potiskajo izobraževanje med nepotrebne izdatke? V strokovni literaturi se že več kot 30 let navajajo zanesljiva spoznanja o razmerah $v$ informacijski družbi znanja, le strokovnjake smo ignorirali in jih z nasmehom odpravili kot utopiste, ker ni bilo političnega poguma, da naredimo potrebne razvojno zgodovinske reze na nacionalni ravni. Majhni bi se lahko ponašali z odličjem.

Družba znanja je sestavljena iz organizacij znanja, profitnih in neprofitnih, vladnih in nevladnih, trajnejših in bolj priložnostnih. Te omogočajo, da se ekspertna znanja združujejo, koordinirajo in povezujejo glede na cilj in nalogo posamezne organizacije. Znanje oživi z uporabo in v skupnih prizadevanjih. Današnja organizacija se bistveno razlikuje od prejšnje. Peter F. Drucker je razčlenil nove paradigme sodobne organizacije (Drucker, 1995: 75-95).

Pozornost bomo namenili nekaterim po Druckerju glavnim paradigmam nove organizacije:

- Temeljna naloga vsake organizacije je, da poveže specializirana znanja $v$ skupno nalogo.

- Povečujejo se napetosti med potrebo družbene skupnosti po stabilnosti in potrebo organizacije po inovacijah in s tem destabi- lizaciji, med posameznikom in organizacijo in medsebojno odgovornostjo.

- Povečuje se zahteva po družbeno odgovornih organizacijah in uravnoteženem odnosu med avtonomijo organizacije in splošnim dobrim.

- Povečujejo se napetosti med specialisti in specializiranim znanjem in potrebo organizacije po timskem delu.

- Sodobna, postmoderna organizacija temelji na inovacijah in s tem povzroča spremembe, destabilizacijo ali celo ustvarjalno destrukcijo in nasprotuje tradicionalnim konzervativnim težnjam družbe, lokalne skupnosti in družine po ohranjanju stabilnosti.

- Temeljna funkcija organizacije je pognati znanje $v$ delovanje kot pripomoček, proces in končni proizvod. Organizacija je stalna sprememba, kajti znanje se stalno in hitro spreminja: danes zanesljiva znanja so jutrišnji nesmisli.

- Vsakdo v organizaciji ne glede na vrsto znanja si bo moral pridobiti nova znanja vsaj vsakih štiri do pet let ali pa bo postal neprimeren. Največje in najgloblje spremembe znanja ne nastajajo na istem področju, prihajajo z drugih področij (mobilni telefoni, pošiljanje SMS vpliva na razvoj jezika). Velike spremembe $v$ znanju povzročajo tudi socialne inovacije (univerza za tretje življenjsko obdobje).

- Najbolj radikalne spremembe $v$ prihodnjih desetletjih se bodo zgodile pod vplivom nove IKT in znanstvenih odkritij, kako se ljudje najbolj učinkovito učijo, prav na področju šolstva, visokega šolstva in izobraževanja odraslih. Izobraževanje je postalo vseživljenjski proces in pomembna podlaga za sodobno organizacijo. 
- V organizacijo naj bo vgrajen vodstveni princip sprememb. Namesto težnje po ohranjanju obstoječega (procesa, proizvoda) naj bo vodilna težnja po spremembi. Naj naredijo nekaj za to, da prejšnje lahko opustijo in uvedejo novo. Organizacijo naj spremlja stalna težnja po izboljšavah. Sodelavci ne smejo zaspati na lovorikah. Uporabijo naj jih za nove začetke. Znanje, s katerim razpolagajo, naj povežejo in uporabijo $v$ novih aplikacijah. Inovacija je splošen in sistematičen proces in podlaga za spremembe.

- Pripravljenost organizacije za spreminjanje zahteva visoko stopnjo decentralizacije vodenja in odgovornosti. Organizacija mora biti sposobna sprejemati hitre odločitve. Zato je odločanje neposredno povezano s samim delom in upoštevanjem vseh preostalih pomembnih dejavnikov. Zato so se spremenile zahteve po znanju in kompetencah zaposlenih.

- Organizacijo je treba zapreti ne glede na trenutno socialno funkcijo, če demografske spremembe, tehnologija in nova znanja dajejo možnosti za novo delovanje. S tem organizacija pomaga okolju, da premaga nepotrebne zaviralne strahove pred inovacijami in spremembami.

- Kulturo neke organizacije določajo naloge, ki jih izvaja, in ne okolje, širša skupnost, v kateri deluje. Organizacija ima svojo kulturo. Da bi opravila postavljene naloge, se mora ravnati po drugih organizacijah s podobnimi cilji pri vodenju in načinu delovanja. Tako bo dala največji prispevek okolju.

- Socialna odgovornost je v skupnosti organizacij inherentna. Organizacija mora imeti dovolj družbene moči, da se lahko samostojno odloča in je dovolj fleksibilna. Neproiz- vodne organizacije (šole, bolnišnice) imajo pogosto večjo družbeno moč in svobodo odločanja od proizvodnih, ker niso odgovorne za posledice. Tovarna avtomobilov, ki je nevede dala v prodajo serijo z napako, mora prevzeti veliko materialno škodo, doleti jo padec ugleda na trgu. Šola za izključene srednješolce, ki so potem prepuščeni cesti in kriminalu, ne odgovarja več.

- Vsaka na znanju temelječa organizacija ima svoj vrednostni sistem. V njem se najbolj izraža širša socialna skupnost. Znanje ne pozna meja.

- Temeljna odgovornost organizacije se spreminja s tipom organizacij. Ekonomska odgovornost je gotovo temeljna pri podjetjih, tako kot je izobraževanje temeljno $v$ šolah ali zdravljenje $v$ bolnišnicah. Med temeljne odgovornosti organizacij sodi tudi zagotavljanje kompetentnih strokovnjakov, vzdrževanje in razvoj njihovega znanja ter s tem ohranjanje ali stopnjevanje kompetenc.

- Organizacijo povezuje in opredeljuje naloga. Organizacija je sredstvo za doseganje ciljev. Učinkovita je, če se na nalogo osredotoči s specializiranimi znanji strokovnjakov. Čim bolj postaja organizacija skupnost strokovnjakov, tem laže je oditi ali se premakniti drugam. Zato vsaka sodobna organizacija nenehno tekmuje za bistveni vir: izobražene kompetentne strokovnjake. Oblikoval se je povsem nov odnos med organizacijo in delavci znanja. Zaposlene v informacijski družbi opredeljujemo kot ljudi, katerih prispevek $k$ sposobnosti je odvisen od tega, ali so jim organizacije dostopne. Imajo glavno produkcijsko sredstvo, znanje, so pa odvisni od organizacije. Pogojno odvisni, saj so zelo mobilni. Drucker je ocenil, da je sredi 90. let število ekspertnih strokov- 
njakov (delavcev znanja) v razvitem svetu obsegalo približno 40 odstotkov vseh delavcev.

- Kapital, vložen v zaposlene strokovnjake (delavce znanja), je presegel kapital, ki je bil kadarkoli vložen $v$ proizvodne delavce. Tudi družbena vlaganja v strokovnjake so večkrat večja od družbenih vlaganj v prejšnje izobraževanje fizičnih delavcev.

- Strokovnjakov ni mogoče učinkovito nadzirati, ker ima vsak od njih največ znanja $v$ organizaciji za področje, za katero odgovarja. Posedujejo glavno proizvodno sredstvo - znanje. Zato so človeški viri v organizaciji dobili najpomembnejše mesto. Ne zadovoljijo se s plačo, zanima jih, ali jim organizacija ponuja optimalne možnosti za udejanjanje njihovega znanja. Zato je sodobna organizacija kot struktura enakih, združba kolegov in družabnikov. Znanje nobenega se ne postavlja više od znanja drugih. Ne obstajajo nobene vnaprej dane več- ali manjvrednosti zaposlenih strokovnjakov. Vsakdo je cenjen po dejanskih dosežkih, koliko prispeva k skupni nalogi. Moderna organizacija deluje timsko in ne pozna šefov in podrejenih.

- Prehod iz stare organizacije v novo je ena najtežjih nalog učenja, ker se morajo opustiti stare navade in vrsta timskega dela. Sodobna organizacija temelji na osebni odgovornosti. Vsak član tima mora biti odgovoren za svoje odločitve. Vsi člani se morajo videti kot izvrševalci.

- Vodstvo v moderni organizaciji ne ukazuje, ampak spodbuja. Glavna pozornost je namenjena ljudem, delu in delovanju. Ne govorimo o znanju, ampak o več specializiranih znanjih, kar se ujema s pluralizmom v družbi. Raznolikost je značilna za razvite družbe.

\section{EKSPLOZIJA VIŠJEGA IN VISOKEGA ŠOLSTVA}

Fran Jessup, sodelavec Univerze v Oxfordu in eden od avtorjev vseživljenjskega izobraževanja, je poudarjal pomen »učeče se družbe«, ko človeka vse v okolju navaja na izobraževanje (turistična društva, hotelska ponudba, razstave in sejmi, potovanja, prijateljstva, bivalna soseska, delovno okolje, zdravljenje, zabava, dnevni tisk, mediji, druženje, literatura, internet). Izobraževanje se na neformalen način povezuje z vsemi drugimi dejavnostmi: pridobitnim delom, političnim delovanjem, kulturnim udejstvovanjem, zabavo in rekreacijo, družinskim življenjem in prijateljevanjem.

Drucker govori o prehodu v »družbo znanja«. Velik korak $v$ to smer so naredili že v prvem obdobju po drugi svetovni vojni, ko so vsi vojni veterani imeli plačan študij na univerzi. Od srede 60. let prejšnjega stoletja dalje so delovale »univerze odprtih vrat«. Ne glede na predhodno izobrazbo se je lahko vpisal vsak, star najmanj 23 let. Odprt dostop do izobraževanja se je uveljavljal na razne načine. Kanada je s satelitskim izobraževalnim programom študija na daljavo pokrila vso državo, tudi redko naseljena območja. Univerze v Evropi so bile bolj konzervativne in elitistično naravnane. Zato so nastajali vzporedni sistemi študija na daljavo. V Angliji so ustanovili Open University, univerzo odprtih vrat za zaposlene in mladino (1969), v Nemčiji Fernstudium (študij na daljavo) v začetku 70. let. Sledile so še druge evropske države. Tekma za višjo in visoko izobrazbo prebivalstva se je začela.

V Sloveniji doživljamo eksplozijo visokega šolstva zadnjih 10 let. Sistematično so se ustanavljale višje šole. Visoke šole in fakultete nastajajo tudi v manjšsih središčih (Velenje, Krško, Kranj). Imamo štiri univerze (Ljubljana, Maribor, Koper, Nova Gorica) in dve nastajajoči univerzitetni središči: Novo mesto in Celje. 
Terciarna izobrazba (višja in visoka šola) je danes to, kar je bila za časa Marije Terezije osnovna šola (primarna izobrazba) ali v industrijski dobi sekundarna raven izobrazbe (srednja šola).

Pa tudi terciarna izobrazba $z$ enim samim študijem ni dovolj. Študenti kombinirajo več študijskih programov, odrasli se vpisujejo na razne specializacije. Terciarna izobrazba je izhodišče za zaposljivost. Ta pa se vzdržuje z dodatnimi izobraževanji in specialnimi znanji prek sistema izobraževanja odraslih.

Zakaj so ljudje $v$ današnji ekonomiji najpomembnejši dejavnik?

Podobno kot je nove paradigme prinesla teorija vseživljenjskega izobraževanja, so se spremenile tudi paradigme dela in ekonomije. Glavno proizvodno sredstvo je znanje.

\section{LITERATURA}

Adult Education and Development (2010). Bonn: DVV (št. 75).

Drucker, P. F. (1996). Managing in the Time of Great Change. New York: Truman Toley Books/ Dutton.

Rifkin, J. (1995). The End of Work/Technology, Jobs and Your Future. New York: G. P. Putman`s Sons.

Dr. Ana Krajnc

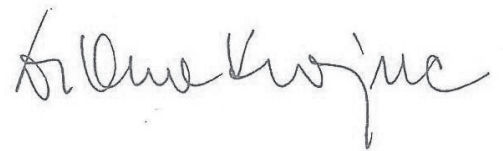

